\title{
Current Status of Long Non-Coding RNAs in Human Breast Cancer
}

\author{
Stefanie Cerk ${ }^{1,2}$, Daniela Schwarzenbacher ${ }^{1,2}$, Jan Basri Adiprasito ${ }^{1,2}$, Michael Stotz ${ }^{1,2}$, \\ Georg C. Hutterer ${ }^{3}$, Armin Gerger ${ }^{1}$, Hui Ling ${ }^{4}$, George Adrian Calin ${ }^{4}$ and Martin Pichler ${ }^{1,2,4, *}$ \\ 1 Division of Oncology, Department of Internal Medicine, Medical University of Graz, Graz 8026, Austria; \\ stefanie.cerk@medunigraz.at (S.C.); daniela.schwarzenbacher@medunigraz.at (D.S.); \\ jan.adiprasito@stud.medunigraz.at (J.B.A.); michael.stotz@medunigraz.at (M.S.); \\ armin.gerger@medunigraz.at (A.G.) \\ 2 Research Unit of Non-coding RNA and Genome Editing in Cancer, Medical University of Graz, \\ Graz 8036, Austria \\ 3 Department of Urology, Medical University of Graz, Graz 8036, Austria; georg.hutterer@medunigraz.at \\ 4 Department of Experimental Therapeutics, The University of Texas MD Anderson Cancer Center, Houston, \\ TX 77054, USA; hling@mdanderson.org (H.L.); gcalin@mdanderson.org (G.A.C.) \\ * Correspondence: martin.pichler@medunigraz.at; Tel.: +43-316-385-81320 \\ Academic Editor: Constantinos Stathopoulos \\ Received: 27 July 2016; Accepted: 26 August 2016; Published: 6 September 2016
}

\begin{abstract}
Breast cancer represents a major health burden in Europe and North America, as recently published data report breast cancer as the second leading cause of cancer related death in women worldwide. Breast cancer is regarded as a highly heterogeneous disease in terms of clinical course and biological behavior and can be divided into several molecular subtypes, with different prognosis and treatment responses. The discovery of numerous non-coding RNAs has dramatically changed our understanding of cell biology, especially the pathophysiology of cancer. Long non-coding RNAs (lncRNAs) are non-protein-coding transcripts $>200$ nucleotides in length. Several studies have demonstrated their role as key regulators of gene expression, cell biology and carcinogenesis. Deregulated expression levels of lncRNAs have been observed in various types of cancers including breast cancer. lncRNAs are involved in cancer initiation, progression, and metastases. In this review, we summarize the recent literature to highlight the current status of this class of long non-coding lncRNAs in breast cancer.
\end{abstract}

Keywords: breast cancer-carcinoma; long non-coding RNA; oncogene; tumor suppressor

\section{Breast Cancer}

According to the American Cancer Association, 1,685,210 new cancer cases and 595,690 cancer deaths are estimated to occur in the United States in 2016 [1]. Breast cancer is currently the most frequently diagnosed cancer in women, with an estimated 246,660 new cases-representing 29\% of all cancer diagnoses in women- and moreover, 40,450 deaths in 2016 in the United States [1]. Breast cancer represents a highly heterogeneous disease in terms of clinical outcomes and biological behavior and thus can be classified with various methods into different subtypes [2]. In recent years, several novel molecular, cellular, tissue- and blood-based prognostic factors have been identified [3-5]. In routine clinical practice, however, relying on immunohistochemical analysis of the estrogen receptor (ER), progesterone receptor and her2/neu receptor, breast cancer is subdivided into hormone receptor positive, her2/neu receptor positive, and (lack of all three receptors) triple negative [6]. Though, the development of novel global transcriptome analysis enabled a further sub-classification into molecular subtypes, including luminal A, luminal B, HER2 enriched, claudin-low, basal-like, and normal breast like [6,7]. Moreover, Ki-67 can be used as a proliferation marker to distinguish 
between strongly endocrine responsive, low proliferative and good prognosis subtype, namely luminal A-like and less endocrine responsive, high proliferative, and poorer prognosis luminal B-like tumors [8].

All these different gene expression signatures are corresponding to classifiers of protein-coding genes but besides the molecular differentiation, each subtype is distinct, regarding clinical prognosis, sensitivity to drugs, as well as the response duration to treatment $[9,10]$. Novel concepts in genetics and molecular biology are leading to improved and higher resolution of the underlying events and increasing complexity in breast cancer biology [11,12].

\section{Long Non-Coding RNAs (lncRNAs)}

The protein-coding world represents only one side of the coin and, recently, tremendous efforts and progress have been made in identifying novel factors and concepts in breast cancer biology. Non-coding RNA molecules, which are by definition transcribed RNAs that never get translated into a protein (therefore named as 'non-coding'), evolved as the new kids on the block in cell biology [13]. The Encyclopedia of DNA Elements (ENCODE) project has revealed that over $80 \%$ of the human genome is transcribed into RNAs with a biochemical function [14], while only about $1.5 \%$ of the human genome actually encodes for proteins [15]. In general, these non-coding RNAs (ncRNAs) represent a broad group of RNAs, including some of the classical 'housekeeping' RNAs, like transfer RNAs, ribosomal RNAs, small nucleolar RNAs, and small nuclear RNAs $[14,16]$. Basically, relying on transcript size, ncRNAs can be classified into two major groups: short ncRNAs, with less than 200 nucleotides (nt) and long ncRNAs (>200 nt). Former can be divided into at least four major classes: microRNAs (miRNAs), short interfering RNAs (siRNAs), transcription initiation RNAs (tiRNAs), and PipW-interacting RNAs (piRNAs) [17]. MicroRNAs in particular have been identified as important regulators of carcinogenesis in all types of cancer [18-21], including breast cancer stem cells [22], whereby they carry a promising potential to show up one day as diagnostic and prognostic cancer biomarkers [23]. IncRNAs, which represent the focus of this review, have received much attention due to their functional relevance in different physiological and pathological processes, as well as their tissue- and developmental-specific expression patterns [13,24-26]. IncRNAs outnumber protein-coding genes [27] and the total number of lncRNAs continue to rise due to improved RNA-sequencing, epigenomic technologies, and computational prediction techniques [28,29]. Most of lncRNAs are not highly conserved in their sequence $[16,17,30]$ and generally show-compared to mRNAs-lower expression levels [26]. The majority of lncRNAs are transcribed by RNA polymerase II and undergo co-transcriptional and post-transcriptional processing events, like $5^{\prime}$-methylguanosine-capping, polyadenylation, splicing, and base modification [16,30,31]. Depending on their location with reference to protein-coding genes, lncRNAs can be classified into sense, antisense, intronic, and intergenic [16,32]. Predominantly, they are located in the nucleus, but nevertheless they are not strictly arranged in one particular compartment, rather, they can be found ubiquitously $[26,33]$.

In general, IncRNAs depict a heterogeneous group of molecules that can be divided according to varying classification systems. One of this sub-classifications divides them into three categories, based on their functional characteristics: non-functional lncRNAs, IncRNAs for which the transcription-event alone is sufficient for their function but the transcript itself is not required, and functional lncRNAs that can act in a cis and/or in trans manner [30,31]. The latter is able to positively or negatively alter the expression or processing of their targets, which can be either coding or non-coding genes [13,34,35].

It is known that lncRNAs mediate several key cellular functions, like regulation of gene expression, genomic reprogramming, X-chromosome inactivation, genomic imprinting, nuclear compartmentalization, nuclear cytoplasmic trafficking, as well as RNA-splicing [16,36-39]. Due to their multiple and heterogeneous mechanisms of action, they characterize common 'master regulators' of gene expression, modulating it at epigenetic-, transcriptional-, as well as posttranscriptional levels $[34,36,37,40-45]$. 
Additionally, lncRNAs are also known to play a pivotal role in the control of the cell cycle and apoptosis; they are able to either act as tumor suppressor genes, whereas others are defined as oncogenes [46-50].

Genome wide associations studies (GWAS) in different cancer types revealed that over $80 \%$ of cancer-associated single nucleotide polymorphisms (SNPs) occur in non-coding regions of the genome. Only 3.3\% of all cancer-related SNPs actually do change the protein amino acid sequence. The majority of SNPs is located in the introns of protein-coding genes (40\%) or intergenic regions $(44 \%)$, indicating an important role of these non-coding sequences in carcinogenesis [51]. Recently, numerous studies have demonstrated that lncRNAs are deregulated in cancer tissues and cells, suggesting that an aberrant expression might be an important contributor to tumorigenesis [49,52-57].

\section{IncRNAs in Breast Cancer}

As mentioned above, several studies were able to demonstrate that lncRNAs are frequently deregulated in various cancers. Meanwhile, numerous lncRNAs have been identified that show different expression patterns in breast cancer tissue compared to normal breast tissue [58-60]. For example, Yang and colleagues have identified more than 1300 lncRNAs that show significantly aberrant expression patterns in the HER-2-enriched subtype of breast cancer by using next generation sequencing [61]. Equally, Shen et al. [14] have figured out that over 1750 lncRNAs were differentially expressed in triple negative breast cancer (TNBC). These results clearly indicate that aberrant expression patterns of lncRNAs might play an important and often underestimated role in breast cancer carcinogenesis.

As already mentioned, IncRNA expression is much more cell-, tissue-, and developmental specific than those of mRNA. Hence, specific lncRNA expression patterns can be a useful tool to distinguish between the various breast cancer subtypes. Lv and colleagues have found differentially expressed lncRNAs to distinguish between TNBC and non-TNBC breast cancer. These lncRNAs may serve as individual diagnostic biomarkers and may be potential targets for individual therapy [10]. IncRNAs can be direct targets of ER in luminal A-like breast cancer cells and can serve as predictive biomarkers [62].Furthermore, Miano et al. [63] have found 133 ER $\alpha$-dependent lncRNAs that are highly specific for luminal-like breast cancer and are therefore very promising in defining this specific subtype of breast cancer.

Another study has also provided a classification system of breast cancer using lncRNA expression [64]. They have found four lncRNA clusters that display different prognoses. The lncRNA HOX antisense intergenic RNA (HOTAIR) was significantly overexpressed in the HER2-enriched subgroup (cluster II), lncRNA HOTAIRM1 showed significantly higher expression in the basal-like subgroup (cluster I) and expression of estrogen receptor was associated with lncRNAs in cluster III and IV [64]. Two further studies have also established a TNBC classification system based on the expression profiles of both mRNAs and lncRNAs. It enables the division of TNBC into subtypes and determines subtype-specific lncRNAs that are potential biomarkers and molecular targets $[65,66]$.

Jiang et al. [67] have developed an integrated mRNA-lncRNA signature that can classify TNBC patients into a low and a high risk group. The latter have higher risks of disease recurrence and achieve less benefit from taxane-based chemotherapy.

To summarize and detail the findings of previously published studies, we are focusing in the following paragraphs on the so far best characterized candidates (Table 1). 
Table 1. Known lncRNAs in breast cancer. This list is demonstrating their location and main function.

\begin{tabular}{|c|c|c|c|}
\hline Name & Location & $\begin{array}{c}\text { Tumor } \\
\text { Suppressor/Oncogene }\end{array}$ & Function \\
\hline H19 & $11 \mathrm{p} 15.5$ & oncogene & miRNA sponge miRNA precursor \\
\hline HOTAIR & $12 \mathrm{q} 13.13$ & oncogene & $\begin{array}{l}\text { molecular scaffold; epigenetic } \\
\text { gene silencing }\end{array}$ \\
\hline MALAT-1 & chromosome 11q13 & oncogene & $\begin{array}{c}\text { activates ERK/MAPK pathway; } \\
\text { induces expression of } B-M Y B \text {; promotes } \\
\text { EMT by activating Wnt signaling }\end{array}$ \\
\hline XIST & inactive $\mathrm{X}$-chromosome & & X-chromosome silencing \\
\hline GAS5 & 1q25.1 & tumor suppressor & interaction with the mTOR pathway \\
\hline PANDAR & $\begin{array}{l}\sim 5 \mathrm{~kb} \text { upstream of } \\
\text { CDKN1A }\end{array}$ & & regulation of G1/S transition \\
\hline CCAT1 & & oncogene & miRNA sponge \\
\hline CCAT2 & $8 \mathrm{q} 24.21$ & oncogene & $\begin{array}{l}\text { regulation of Wnt/ } \beta \text {-catenin } \\
\text { signaling pathway }\end{array}$ \\
\hline UCA1 & 19p13.12 & oncogene & $\begin{array}{l}\text { microRNA sponge; regulation of } \\
\text { KLF4-KRT6/13 signalling pathway }\end{array}$ \\
\hline EPB41L4A-AS2 & $5 p 22.2$ & tumor suppressor & unknown \\
\hline BC040587 & $3 q 13.31$ & tumor suppressor & unknown \\
\hline SPRY4-IT1 & chromosome 5 & oncogene & \\
\hline NBAT-1 & & tumor suppressor & mediating transcriptional silencing \\
\hline AK058003 & $10 \mathrm{q} 22$ & oncogene & $\begin{array}{l}\text { regulating } \gamma \text {-synuclein gene } \\
\quad(S N C G) \text { expression }\end{array}$ \\
\hline Z38 & & oncogene & unknown \\
\hline FGF14-AS2 & & tumor suppressor & unknown \\
\hline MVIH & & oncogene & unknown \\
\hline LINK-A & & oncogene & Rrgulation of HIF1 $\alpha$ signaling pathway \\
\hline DSCAM-AS1 & & oncogene & unknown \\
\hline
\end{tabular}

\section{IncRNA Candidates in Breast Cancer}

\section{1. $H 19$}

The $H 19$ gene was one of the first discovered genes that was recognized to be submitted to genomic imprinting. It is located in the 11 p15.5 region within 200 kilobase $(\mathrm{kb})$ downstream of the Insulin-like growth factor 2 (IGF-2) gene [68]. These two genes are oppositely imprinted, IGF-2 is transcribed from the paternal allele [69], while $H 19$ is only maternally expressed [70]. The $H 19$ gene is transcribed by RNA polymerase II and encodes a $2.3 \mathrm{~kb}$ lncRNA. The transcript is spliced, polyadenylated, capped, and translocated into the cytoplasm and it is associated with polysomes [71-74]. H19 expression is developmentally regulated and it is highly expressed in extraembryonic tissue (placenta), as well as embryo proper and fetal tissue. After birth, its expression is repressed except in a few adult tissues, including mammary and adrenal gland, as well as in the uterus [72,73]. H19 upregulation has been reported in various cancers, such as bladder-, lung-, esophageal-, cervical-, and breast cancer [74-80], whereby it is often associated with poor prognosis [81-83]. It regulates genes involved in metastasis and blood vessel development, suggesting an important role in tumor invasion and angiogenesis [72,84]. Further, H19 operates as an oncogene through different mechanisms. It can function as a Myc-upregulated gene to potentiate tumorigenesis in several cell types, including breast cancer cells [85]. It also has been reported that $\mathrm{H} 19$ acts as a molecular sponge to regulate members of the let-7 miRNA family, which all play important roles in development, metabolism, and cancer [86]. 
Moreover, Cai and Cullen have described that H19 is able to function as a precursor of miR-675, suggesting that it might act as a gene-expression regulator at the post-transcriptional level [87].

On top of that, H19 RNA is also involved in epithelial to mesenchymal transition (EMT), as well as in mesenchymal to epithelial transition (MET). It has been shown that numerous EMT inducers lead to increased H19/miR-675 expression. Furthermore, H19 RNA suppresses the expression of the E-cadherin protein and is essential for upregulation of the EMT related transcription factor Slug by Transforming Growth Factor $\beta$ (TGF- $\beta$ ). In contrast, it was also reported that miR-675 might represent a MET promoter by downregulating the EMT key mediator Twist-related protein 1 (Twist1) $[84,88,89]$. In breast cancer, H19 overexpression promotes tumor progression [90] and leads to increased cell proliferation due to promoting the G-S transition through positive control by the transcription factor E2F1 [72].

Adriaenssens et al. [79] have reported that an increase of $H 19$ gene expression can be observed in breast cancer compared to healthy tissues and that upregulation of the H19 gene is correlated with the tumor grades and the presence of estrogen- as well as with progesterone receptors.

Vennin and colleagues have shown that an overexpression of H19/miR-675 enhances breast cancer cell aggressiveness, including an increased proliferation and migration rate in vitro, and increases tumor growth and metastasis in vivo. Additionally, they identified the ubiquitin ligase E3 family $(c-C b I$ and $C b I-b)$ as direct targets of miR-675 in breast cancer cells, providing novel mechanistic insights into a role of lncRNA H19 in breast cancer development [73].

\subsection{HOTAIR}

In 2007, Rinn et al. [91] have identified HOX antisense intergenic RNA (HOTAIR) that is located on chromosome 12q13.13 in the HOXC locus. It depicts a trans-acting, spliced, and polyadenylated IncRNA that is $2.2 \mathrm{~kb}$ in length and is considered an oncogene [91-93].

HOTAIR functions as molecular scaffold and interacts with the methyltransferase Polycomb Repressive Complex 2 (PRC2). It regulates chromosome occupancy by enhancer of zeste homolog 2 (EZH2 -a subunit of PRC2), resulting in histone H3 lysine-27 trimethylation of the HOXD locus [91-93]. Furthermore, HOTAIR recruits PRC2 to specific target genes genome-wide, leading to histone H3 lysine-27 trimethylation and epigenetic silencing of metastasis suppressor genes [93-95]. Moreover, HOTAIR is able to interact with the Lysine-specific demethylase 1 (LSD1) complex, leading to epigenetic gene silencing due to demethylation of histone H3 at lysine 4 [96,97]. Through these functions, HOTAIR seems to affect the gene expression of several genes involved in various cellular functions [94]. In general, HOTAIR is ubiquitously overexpressed in most human cancers and correlated with tumor invasion, progression, metastasis, and poor prognosis [91,93]. Its pervasive deregulation in cancers was first observed in breast cancer. Gupta and colleagues have reported higher HOTAIR expression levels in primary breast tumors compared with adjacent tissue [94]. Estradiol transcriptionally induces HOTAIR via functional estrogen response elements within the promoter region, which might contribute to breast cancer progression $[98,99]$. Tao and colleagues have recently demonstrated that estradiol induces HOTAIR expression via G-protein-coupled estrogen receptor-1 mediated miR-148a inhibition in breast cancer [100]. Padua et al. [101] have showed that HOTAIR overexpression upregulates the genes related to EMT. In addition, they observed elevated HOTAIR levels in a colon cancer stem cell subpopulation compared with a non-stem cell subpopulation, indicating that HOTAIR might be required for EMT and stemness maintenance.

Particularly in breast cancer, HOTAIR is able to indirectly downregulate $m i R-7$ via HoxD10 inhibition, resulting in EMT progression. miR-7 represents a metastasis-suppressing miRNA that can reverse EMT by downregulating the signal transducer and activator of transcription 3 (STAT3) pathway in breast cancer cells [102]. 


\subsection{MALAT-1}

The metastasis-associated lung adenocarcinoma transcript 1 (MALAT-1) is located on chromosome $11 \mathrm{q} 13$ and encodes an $8 \mathrm{~kb}$ lncRNA. MALAT-1 defines one of the first ever known ncRNAs that are associated with lung cancer. Since its discovery, several studies have reported the link of MALAT-1 to other cancers, including gallbladder-, cervical-, non-small cell lung- (NSCLC), colorectal-, and breast cancer. In most cases, MALAT-1 is upregulated in cancer and is associated with metastasis, cell proliferation, apoptosis, and migration, as well as with clinically unfavorable prognostic parameters [16,49,103-106].

MALAT-1 activates the MAPK extracellular signal-regulated kinase/mitogen-activated protein kinase (ERK/MAPK) pathway, resulting in an increased proliferation of gallbladder cancer cells [106]. Another mechanistic study has demonstrated that MALAT-1 induces the expression of the oncogenic transcription factor myb-related protein B (B-MYB) that is required for the transcription of various genes involved in mitotic progression [107]. Furthermore, Ying and colleagues have reported that MALAT-1 might lead to bladder cancer cell migration due to the promotion of EMT by activating Wnt signaling [108].

A recent study performed by $\mathrm{Xu}$ et al. [109] was able to demonstrate that MALAT-1 is downregulated in breast tumor cell lines as well as in breast cancer tissue. MALAT-1 regulates metastasis in breast cancer by inducing EMT via activation of the phosphatidylinositide 3-kinase-protein kinase B (PI3K-AKT) pathway.

Wang et al. [110] have recently demonstrated that MALAT-1 is linked to overall survival, recurrence free survival, and death-free survival, however, association between MALAT-1 levels and clinical features like TNM stage, lymph node metastasis, and distant metastasis were diverse in different types of cancer. Therefore, MALAT-1 may serve as a biomarker, but its value differs in various cancers.

In addition, another study has not found a link between MALAT-1 overexpression TNM grade, lymph node status and tumor size, indicating that high levels of MALAT-1 do not have a major role in the aggressive behavior of breast carcinoma [111]. The same group has found an alternative splice variant, namely $\Delta$ sv-MALAT-1 that show very different expression pattern relative to full length MALAT-1. $\Delta$ sv-MALAT-1 was mainly downregulated in breast tumors, therefore it can serve as an independent prognostic marker. Its expression was associated with alterations of the pre-mRNA alternative splicing machinery, the Drosha-DGCR8 complex that is required for ncRNA biogenesis as well as with an activation of the PI3K-AKT pathway [111].

In TNBC and HER2+ breast cancer, MALAT-1 expression could be used as a potential prognostic marker, but not in luminal patients. In TNBC and HER2+ subtypes, MALAT-1 level could be used to predict tumor recurrence and metastasis in lymph-node negative patients [112].

\subsection{XIST}

The $\mathrm{X}$ inactive-specific transcript (XIST) is an $17 \mathrm{~kb}$ spliced and polyadenylated lncRNA [113] encoded by the XIST gene, which is located in the X-inactivation center on the inactive X-chromosome [114]. XIST represents the key player of X-chromosome silencing in female cells. It is typically expressed by all female somatic cells, but its expression has been found to be lost in female breast-, ovarian-, as well as cervical cancer cell lines. Typically, only one active X-chromosome is present in human cells, but in human cancers, a loss of a normal X-chromosome can be observed along with dysregulated XIST expression [114,115]. Cancer cells have shown either downregulation or upregulation of XIST, suggesting its complex and controversial role in cancer biology $[114,116]$.

\subsection{GAS5}

The Growth arrest-specific 5 (GAS5) gene is located on chromosome 1q25.1 and encodes small nucleolar RNAs, microRNAs, and PIWI-interacting RNAs, in addition to lncRNA. It consists of 
12 exons, which are alternatively spliced into two possible mature lncRNAs [117]. GAS5 lncRNA accumulates in growth arrested cells due to interaction with the mechanistic Target of Rapamycin (mTOR) pathway and through nonsense mediated decay [118].

The involvement of GAS5 in human cancers was first studied in breast cancer. In 2009, Mourtada-Maarabouni and colleagues reported that GAS5 is downregulated in breast cancer tissues [119]. Generally, GAS5 is found to be downregulated in various cancers and low expression levels are often predictive of poor prognosis in cancer patients [50,117,119-121]. Moreover, GAS5 promotes cell proliferation and /or apoptosis in different cell types, including breast cancer cells and its tumor suppressor role is indicated by its inhibition of breast tumor growth [117,122].

Li et al. [123] have found that GAS5 levels are decreased in trastuzumab-resistant SKBR-3/Tr cells and in breast cancer tissue from trastuzumab-treated patients. GAS5 knockdown increased cell proliferation and tumor growth in vivo and low levels of GAS5 correlated with histological grade and advanced TNM stage. That indicates that GAS5 is reduced by trastuzumab and may act as a tumor suppressor in trastuzumab-resistant breast cancer.

\subsection{PANDAR}

PANDAR (promoter of CDKN1A antisense DNA damage activated RNA) is located approximately $5 \mathrm{~kb}$ upstream of the cell cycle gene Cyclin-Dependent Kinase Inhibitor 1A (CDKN1A) transcription start site and encodes for a $1.5 \mathrm{~kb}$ lncRNA. Upon DNA damage, expression of PANDAR is induced by $\mathrm{p} 53$. PANDAR interacts with the transcription factor NF-YA to restrict the expression of pro-apoptotic genes and enables cell cycle arrest. Silencing of PANDAR increases the DNA damage-induced apoptosis and PANDAR has been found to control the entry and exit into and out of senescence [54,124-126]. Han and colleagues have reported that PANDAR is downregulated in NSCLC and low expression levels are associated with poor prognosis [127].

Several controversially discussed studies have demonstrated that PANDAR is upregulated in hepatocellular carcinoma, gastric cancer, and breast cancer $[54,128,129]$, indicating its potentially complex role in cancer. As mentioned, PANDAR is upregulated in breast cancer tissues, as well as in breast cancer cell lines and functions as a tumor-promoting lncRNA by regulating G1/S transition. PANDAR-mediated G1/S transition and promotion of cell growth is, at least in parts, a result of the suppression of its downstream target $\mathrm{p} 16^{\mathrm{INK} 4 \mathrm{~A}}$ [54].

\subsection{CCAT1}

Colon cancer-associated transcript 1 (CCAT1) is a $2.6 \mathrm{~kb}$ transcript [130]. CCAT1 has been found to be upregulated in many cancers, including gastric-, hepatocellular-, gallbladder-, colorectal-, colon-, and breast cancer [52,130-135]. Its increased expression is associated with clinical stage, lymph node metastases, and survival after surgery in colon cancer patients [130], as well as with poor prognosis in hepatocellular carcinoma patients [134].

$\mathrm{Ma}$ and colleagues have reported that CCAT1 upregulates the miRNA-218-5p target gene B cell-specific Moloney murine leukemia virus integration site 1 (Bmi1) by acting as miRNA-218-5p sponge, resulting in an increased proliferation and invasiveness of gallbladder cancer cells [135]. Upregulation of CCAT1 promotes proliferation and migration of hepatocellular carcinoma cells, due to its function as let-7 sponge [134].

A factor potentially contributing to the deregulation of CCAT1, is c-Myc, an important regulator of cell cycles, proliferation, differentiation, and apoptosis that is also known as the oncogene $[131,136]$. c-Myc might promote CCAT1 transcription by directly binding to its promoter region, resulting in an upregulation of CCAT1 expression [130,137]. Upregulated CCAT1 expression correlates with aggressive disease progression and poor prognosis in breast cancer patients, albeit the detailed functional mechanisms in breast cancer are still unknown [52]. 


\subsection{CCAT2}

Colon cancer-associated transcript 2 (CCAT2) represents a novel lncRNA located at the highly conserved 8q24.21 region [138]. The group around George A. Calins lab was able to demonstrate that an elevated CCAT2 expression is associated with the development of metastases and poor prognosis within various cancers, including breast cancer [53,139-143].

Cai et al. [139] have figured out that CCAT2 is upregulated in breast cancer tissues compared to adjacent non-tumor tissues and that its expression is correlated with clinico-pathological prognostic factors. Patients with an elevated CCAT2 expression had a significantly poorer prognosis than those with low expression levels. Moreover, the relative CCAT2 expression level correlated with the overall survival rate of breast cancer patients.

Suppressing CCAT2 expression by siRNAs leads to a decreased cell proliferation and invasion in vitro and inhibits tumorigenesis in vivo. A knockdown of CCAT2 affects the Wnt/ $\beta$-catenin signaling pathway, by suppressing $\beta$-catenin activity, whose activation leads to the development of human cancers, including breast cancer [139]. Taken together, these findings indicate that an elevated CCAT2 expression is associated with the progression and development of breast cancer.

Redis et al. [142] have identified the tissue- and subcellular localization of CCAT2 in breast cancer by in situ hybridization, using 16 non-tumor- and 18 tumor samples. CCAT2 appeared to have higher expression levels in the epithelial component of breast cancer tissues compared with those of non-tumor tissues. CCAT2 was detected in the nucleus as well as in the cytoplasm, with a more intense staining within the nuclear compartment, indicating enrichment within this compartment. The same group of authors have recently proposed different metabolic pathway activation patterns depending on a single nucleotide polymorphism, which influences the 3-dimensional structure of CCAT2, indicating the well-known conformational importance of lncRNA functions [144].

\subsection{UCA1}

The Urothelial carcinoma associated 1 (UCA1) gene is located on the positive strand of chromosome 19p13.12. The sequence consists of three exons and at least three splice variants do exist that are $1.4,2.2$, and $2.7 \mathrm{~kb}$, respectively in length, whereof the $1.4 \mathrm{~kb}$ transcript is the most abundant one $[145,146]$.

The UCA1 gene encodes for an lncRNA that is highly expressed in various carcinomas including bladder-, colorectal- and breast cancer [145,147-149], suggesting that UCA1 might serve as a potential biomarker for diagnostic purposes in the future [146].

Moreover, UCA1 acts as a microRNA sponge, which has been demonstrated by Nie and colleagues [150]. The authors have pointed out that a UCA1 upregulation promotes the proliferation of NSCLC cells partly through acting as an $m i R-193 a-3 p$-sponge [150]. Na and colleagues have reported that lncRNA UCA1 regulates the proliferation in prostate cancer cells through regulation of kruppel-like factor 4 (KLF4) and keratin 6/13. UCA1 loss-of-function experiments inhibited cell proliferation and induced apoptosis, at least partly, through inactivation of the KLF4-KRT6/13 signalling pathway [151].

In breast cancer, UCA1 modulates cell growth and apoptosis, at least partially by interacting with miR-143, a microRNA with a tumor suppressive role in breast cancer [147] and colorectal cancer [152]. Through direct binding, UCA1 lowers the expression levels and reduces the biological effects of miR-143 [147]. Huang et al. [153] have demonstrated the oncogenic role of UCA1 in breast cancer, by showing that UCA1 promotes cell growth in vitro and in vivo. Their study suggests that UCA1 suppresses the tumor suppressor p27 through interaction with heterogeneous nuclear ribonucleoproteins I (hnRNP I).

\subsection{EPB41L4A-AS2}

The EPB41L4A-AS2 gene is located on chromosome 5p22.2 and encodes for a recently identified antisense lncRNA of unknown function. Xu et al. [154] have demonstrated that overexpression of 
EPB41L4A-AS2 inhibits tumor cell growth in renal-, lung-, and breast cancer cell lines, suggesting that it might act as a tumor suppressor by mediating cell proliferation. Downregulation of EPB41L4A-AS2 is linked with poor survival in these three cancers, indicating that its downregulation might contribute to tumorigenesis, as well as disease progression.

In breast cancer, EPB41L4A-AS2 is associated with tumorigenesis and chemoresistance, and it seems to be involved in the estrogen synthesis regulation. Furthermore, the expression pattern differs with tumor grade, tumor size, disease stage, receptor status, and molecular subtype, indicating that different molecular subtypes are more or less associated with this lincRNA [154].

\subsection{1. $B C 040587$}

BC040587 depicts a novel lncRNA located on chromosome 3q13.31. The expression level of BC040587 in breast cancer tissue, as well as in breast cancer cell lines are low in comparison to normal tissues and cell lines, respectively, indicating its potential function as a tumor suppressor. Patients with a low BC040587 expression pattern tend to have a higher risk of poor grade of tumor differentiation. Moreover, overall survival was significantly decreased in patients with a low BC040587 expression compared to those with an elevated expression pattern, indicating its potential clinical relevance [155].

\subsection{SPRY4-IT1}

SPRY4 intronic transcript 1 (SPRY4-IT1) is $708 \mathrm{bp}$ in length and located on chromosome 5 [156]. Several studies were able to demonstrate that SPRY4-IT1 promotes cell growth, invasion and inhibits apoptosis in several types of cancer, including breast cancer [156-160]. Recently, Ru and colleagues have reported that SPRY4-IT1 promotes EMT, invasion, and migration through association with Snail1 in osteosarcoma cells [160]. Snail1 is a transcription factor of the C2H2-type zinc-finger family that induces EMT through silencing of the E-cadherin expression [161]. Shi et al. have reported that an increased expression of SPRY4-IT1 is associated with a larger tumor size and later stage of tumor development in breast cancer patients and that a SPRY4-IT1 knockdown leads to suppressed cell proliferation and induced apoptosis in breast cancer cells. Additionally, the authors identified ZNF703 as a downstream target gene and demonstrated that ZNF703 promotes proliferation and suppresses apoptosis in vivo [156].

\subsection{NBAT-1}

lncRNA neuroblastoma associated transcript-1 (NBAT-1) is downregulated in numerous types of cancer, including breast cancer, which suggests a potential function as tumor suppressor [48,162,163]. A low expression of NBAT-1 increases cell migration and invasion and is correlated with poor prognosis in neuroblastoma, as well as in clear cell renal cell carcinoma patients [48,163]. A mechanistic study was able to demonstrate that NBAT-1 acts as a tumor suppressor by interacting with EZH2, a subunit of the global gene expression regulator PRC2 complex [163]. EZH2 expression is associated with increased tumor cell proliferation and regulates cell invasion mostly through mediating transcriptional silencing of tumor suppressor genes like E-cadherin [164-166].

In breast cancer, low NBAT-1 expression levels are associated with poor survival, as well as the development of lymph node metastases. Hu et al. [162] have showed that NBAT-1 upregulates Dickkopf WNT signaling pathway inhibitor 1 (DKK1), through interacting with EZH2. DKK1 represents an inhibitor of the WNT signaling pathway and might be responsible for NBAT-1's effect in suppressing migration and invasion of breast cancer cells.

\subsection{AK058003}

IncRNA AK058003 is an 1197 bp long transcript located on the forward strand on locus 10q22 [167]. The expression levels have been shown to be elevated in breast cancer tissues and its upregulation promotes proliferation, invasion, and metastasis by regulating the $\gamma$-synuclein gene (SNCG) expression. SNCG (also known as breast cancer-specific protein 1) encodes a synaptic protein and its expression 
is closely associated with tumor invasion and metastasis in various cancers, including esophageal-, stomach-, liver-, and breast cancer, as well as with clinical stage and lymph node metastases $[168,169]$.

\subsection{Z38}

The newly discovered lncRNA Z38 is highly expressed in breast cancer cells and breast cancer tissue. A knock-down of Z38 expression using siRNAs suppresses cell proliferation, tumor growth and tumorigenesis, and induces apoptosis. However, detailed functional mechanisms involved in the regulatory roles of Z38 in cancers are still unknown [47].

\subsection{FGF14-AS2}

A recently published study conducted by Yang et al. [170] has demonstrated that lncRNA FGF14-AS2, which is an anti-sense transcript for FGF14, is significantly downregulated in breast cancer tissue compared with adjacent normal tissue. Furthermore, the expression of FGF14-AS2 has been shown to be negatively correlated with tumor size, lymph node metastases, and clinical stage in two independent cohorts, indicating that it might act as a tumor suppressor gene. Specifically, this finding was confirmed when integrating FGF14-AS2 into multivariate analyses [170]. However, due to the lack of experimental data, an interpretation of these findings is difficult and not connected to an appropriate biological context yet.

\subsection{7. $M V I H$}

IncRNA associated with microvascular invasion in hepatocellular carcinoma (MVIH) has been found to be upregulated in hepatocellular carcinoma (HCC) [171], non-squamous cell lung cancer (NSCLC) [172] and breast cancer cells [173]. In HCC, it promotes tumor growth and intrahepatic metastases by activating angiogenesis [171]. In NSCLC, MVIH promotes cell proliferation and invasion of cancer cells. Moreover, the MVIH expression levels correlate with TNM stages, tumor size, lymph node metastasis, and poor prognosis [172]. In breast cancer, elevated expression levels of MVIH influence cell proliferation, apoptosis, and the cell cycle, whereby it correlates with high Ki67 staining, poor overall- and disease-free survival [173].

\subsection{LINK-A}

Long-Intergenic Noncoding RNA for Kinase Activation (LINK-A) is a 1540 bp transcript that is located in the cytoplasm. Basal-like breast cancer exhibits significantly elevated LINK-A expression relative to HER2+, luminal A-like, luminal B-like, and normal-like subtypes. Furthermore, LINK- $A$ correlates with unfavorable recurrence free survival for breast cancer patients.

Mechanistically, LINK-A is critical for growth factor-induced normoxic Hypoxia-Inducible Factor $\alpha(\mathrm{HIF} 1 \alpha)$ signaling pathway. It is required for a Heparin-binding-epidermal-growth-factor-like growth factor (HB-EGF)-triggered, Epidermal Growth Factor Receptor (EGFR): glycoprotein non-metastatic $b$ (GPNMB) heterodimer-mediated recruitment of breast tumor kinase (BRK) to GPNMB. This results in enzymatic activation of BRK that then, together with Leucinreicher-Repeat-Serin/Threoninkinase 2 (LRRK2), is also recruited by LINK-A, phosphorylate HIF1 $\alpha$ at Tyr565, and Ser797, respectively. The Tyr565 phosphorylation interferes with Pro564 hydroxylation, resulting to normoxic HIF1 $\alpha$ stabilization, while phosphorylation of Ser797 enables HIF1 $\alpha$-p300 interaction, leading to activation of HIF1 $\alpha$ target genes upon HB-EGF stimulation. LINK-A expression as well as the activation of LINK-A-dependent HIF1 $\alpha$ signaling pathway correlate with TNBC, promote breast cancer glycolysis reprogramming and tumorigenesis. Therefore, LINK-A may serve as potential target to block a normoxic HIF1 $\alpha$ signaling pathway in TNBC [174].

\subsection{DSCAM-AS1}

DSCAM-AS1 is an estrogen receptor $\alpha(E R \alpha)$-dependent lncRNA and is antisense intronic within the DSCAM (Down Syndrome Cell Adhesion Molecule) gene. It highly specific for luminal breast 
cancer and can therefore be used as biomarkers of this subtype. DSCAM-AS1 knockdown mimics some features of $E R \alpha$ silencing, like reduction of cellular growth, increase of apoptosis, and induction of EMT markers without influencing ER $\alpha$ expression. To understand the mechanistic function of DSCAM-AS1, further studies are needed [63].

\section{Summary}

Within a relatively short period of time, IncRNAs have become recognized as a significant part of the eukaryotic transcriptome. They obviously play a crucial role in diverse important cellular processes, like epigenetic regulation, chromatin remodeling and splicing, whereby their dysregulation is able to contribute to the development and progression of cancer. IncRNAs are acting via manifold mechanisms and a detailed characterization of their modes of action will allow their use as potential biomarkers for diagnostic, as well as therapeutic purposes in the treatment of cancer patients in the future.

Acknowledgments: This research was supported in part by a Research Grant of the Austrian Society of Hematology and Medical Oncology (to Daniela Schwarzenbacher). Writing and drafting of this manuscript has been partly supported by a fund of the Oesterreichische Nationalbank No. 15888 (to Georg C. Hutterer) and No. 14869 (to Martin Pichler). Furthermore, Research activities from Stotz are supported by a START grant from the Medical University of Graz and Hans und Blanca Moser Foundation for Early Cancer Research.

Author Contributions: All authors contributed to the drafting, writing, and reviewing of this article.

Conflicts of Interest: The authors declare no conflict of interest.

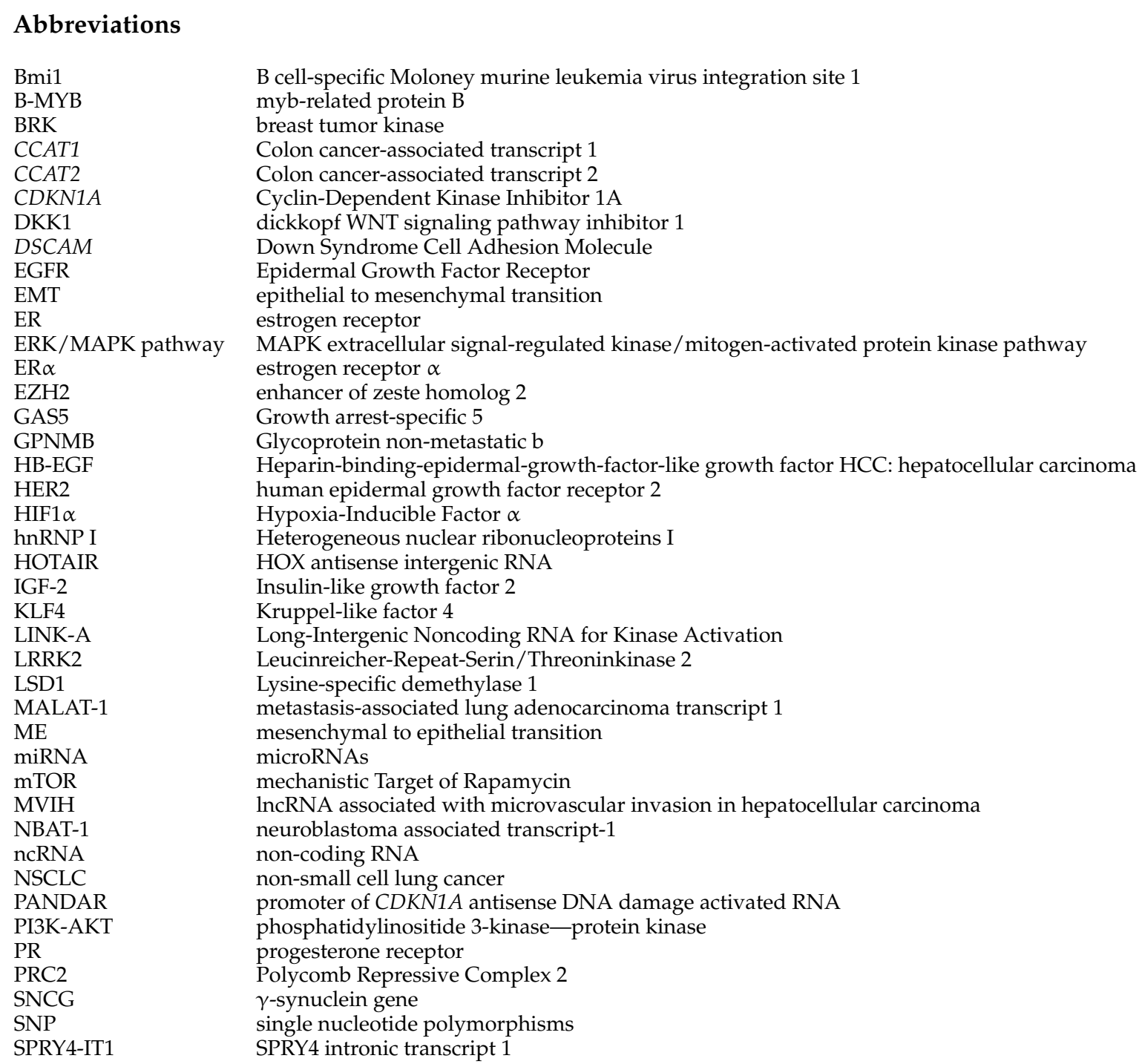


STAT3

TGF- $\beta$

TNBC

Twist1

UCA1

XIST

\author{
Signal transducer and activator of transcription 3 \\ Transforming Growth Factor $\beta$ \\ triple negative breast cancer \\ Twist-related protein 1 \\ Urothelial carcinoma associated 1 \\ $\mathrm{X}$ inactive-specific transcript
}

\section{References}

1. Siegel, R.L.; Miller, K.D.; Jemal, A. Cancer statistics, 2016. CA Cancer J. Clin. 2016, 66, 7-30. [CrossRef] [PubMed]

2. Weigelt, B.; Geyer, F.C.; Reis-Filho, J.S. Histological types of breast cancer: How special are they? Mol. Oncol. 2010, 4, 192-208. [CrossRef] [PubMed]

3. Schwarzenbacher, D.; Stiegelbauer, V.; Deutsch, A.; Ress, A.L.; Aigelsreiter, A.; Schauer, S.; Wagner, K.; Langsenlehner, T.; Resel, M.; Gerger, A.; et al. Low spinophilin expression enhances aggressive biological behavior of breast cancer. Oncotarget 2015, 6, 11191-11202. [CrossRef] [PubMed]

4. Krenn-Pilko, S.; Langsenlehner, U.; Stojakovic, T.; Pichler, M.; Gerger, A.; Kapp, K.S.; Langsenlehner, T. An elevated preoperative plasma fibrinogen level is associated with poor disease-specific and overall survival in breast cancer patients. Breast 2015, 24, 667-672. [CrossRef] [PubMed]

5. Krenn-Pilko, S.; Langsenlehner, U.; Stojakovic, T.; Pichler, M.; Gerger, A.; Kapp, K.S.; Langsenlehner, T. The elevated preoperative derived neutrophil-to-lymphocyte ratio predicts poor clinical outcome in breast cancer patients. Tumour Biol. 2016, 37, 361-368. [CrossRef] [PubMed]

6. Holliday, D.L.; Speirs, V. Choosing the right cell line for breast cancer research. Breast Cancer Res. $2011,13$. [CrossRef] [PubMed]

7. Prat, A.; Perou, C.M. Deconstructing the molecular portraits of breast cancer. Mol. Oncol. 2011, 5, 5-23. [CrossRef] [PubMed]

8. Coates, A.S.; Winer, E.P.; Goldhirsch, A.; Gelber, R.D.; Gnant, M.; Piccart-Gebhart, M.; Thürlimann, B.; Senn, H.J.; Panel Members. Tailoring therapies-Improving the management of early breast cancer: St. Gallen International Expert Consensus on the Primary Therapy of Early Breast Cancer 2015. Ann. Oncol. 2015, 26, 1533-1546. [CrossRef] [PubMed]

9. Sorlie, T.; Perou, C.M.; Tibshirani, R.; Aas, T.; Geisler, S.; Johnsen, H.; Hastie, T.; Eisen, M.B.; van de Rijn, M.; Jeffrey, S.S.; et al. Gene expression patterns of breast carcinomas distinguish tumor subclasses with clinical implications. Proc. Natl. Acad. Sci. USA 2001, 98, 10869-10874. [CrossRef] [PubMed]

10. Lv, M.; Xu, P.; Wu, Y.; Huang, L.; Li, W.; Lv, S.; Wu, X.; Zeng, X.; Shen, R.; Jia, X.; et al. IncRNAs as new biomarkers to differentiate triple negative breast cancer from non-triple negative breast cancer. Oncotarget 2016, 7, 13047-13059. [PubMed]

11. Ciriello, G.; Gatza, M.L.; Beck, A.H.; Wilkerson, M.D.; Rhie, S.K.; Pastore, A.; Zhang, H.; McLellan, M.; Yau, C.; Kandoth, C.; et al. Comprehensive Molecular Portraits of Invasive Lobular Breast Cancer. Cell 2015, 163, 506-519. [CrossRef] [PubMed]

12. Robinson, D.R.; Wu, Y.M.; Vats, P.; Su, F.; Lonigro, R.J.; Cao, X.; Kalyana-Sundaram, S.; Wang, R.; Ning, Y.; Hodges, L.; et al. Activating ESR1 mutations in hormone-resistant metastatic breast cancer. Nat. Genet. 2013, 45, 1446-1451. [CrossRef] [PubMed]

13. Ling, H.; Vincent, K.; Pichler, M.; Fodde, R.; Berindan-Neagoe, I.; Slack, F.J.; Calin, G.A. Junk DNA and the long non-coding RNA twist in cancer genetics. Oncogene 2015, 34, 5003-5011. [CrossRef] [PubMed]

14. Shen, X.; Xie, B.; Ma, Z.; Yu, W.; Wang, W.; Xu, D.; Yan, X.; Chen, B.; Yu, L.; Li, J.; et al. Identification of novel long non-coding RNAs in triple-negative breast cancer. Oncotarget 2015, 6, 21730-21739. [CrossRef] [PubMed]

15. Lander, E.S.; Linton, L.M.; Birren, B.; Nusbaum, C.; Zody, M.C.; Baldwin, J.; Devon, K.; Dewar, K.; Doyle, M.; FitzHugh, W.; et al. Initial sequencing and analysis of the human genome. Nature 2001, 409, 860-921. [CrossRef] [PubMed]

16. Vikram, R.; Ramachandran, R.; Abdul, K.S. Functional significance of long non-coding RNAs in breast cancer. Breast Cancer 2014, 21, 515-521. [CrossRef] [PubMed]

17. Zhang, F.; Zhang, L.; Zhang, C. Long noncoding RNAs and tumorigenesis: Genetic associations, molecular mechanisms, and therapeutic strategies. Tumour Biol. 2016, 37, 163-175. [CrossRef] [PubMed] 
18. Ling, H.; Krassnig, L.; Bullock, M.D.; Pichler, M. MicroRNAs in Testicular Cancer Diagnosis and Prognosis. Urol. Clin. N. Am. 2016, 43, 127-134. [CrossRef] [PubMed]

19. Thomas, J.; Ohtsuka, M.; Pichler, M.; Ling, H. MicroRNAs: Clinical Relevance in Colorectal Cancer. Int. J. Mol. Sci. 2015, 16, 28063-28076. [CrossRef] [PubMed]

20. Troppan, K.; Wenzl, K.; Deutsch, A.; Ling, H.; Neumeister, P.; Pichler, M. MicroRNAs in diffuse large B-cell lymphoma: Implications for pathogenesis, diagnosis, prognosis and therapy. Anticancer Res. 2014, 34, 557-564. [PubMed]

21. Bezan, A.; Gerger, A.; Pichler, M. MicroRNAs in testicular cancer: Implications for pathogenesis, diagnosis, prognosis and therapy. Anticancer Res. 2014, 34, 2709-2713. [PubMed]

22. Schwarzenbacher, D.; Balic, M.; Pichler, M. The role of microRNAs in breast cancer stem cells. Int. J. Mol. Sci. 2013, 14, 14712-14723. [CrossRef] [PubMed]

23. Pichler, M.; Calin, G.A. MicroRNAs in cancer: From developmental genes in worms to their clinical application in patients. Br. J. Cancer 2015, 113, 569-573. [CrossRef] [PubMed]

24. Malih, S.; Saidijam, M.; Malih, N. A brief review on long noncoding RNAs: A new paradigm in breast cancer pathogenesis, diagnosis and therapy. Tumour Biol. 2016, 37, 1479-1485. [CrossRef] [PubMed]

25. Sana, J.; Faltejskova, P.; Svoboda, M.; Slaby, O. Novel classes of non-coding RNAs and cancer. J. Transl. Med. 2012, 10. [CrossRef] [PubMed]

26. Derrien, T.; Johnson, R.; Bussotti, G.; Tanzer, A.; Djebali, S.; Tilgner, H.; Guernec, G.; Martin, D.; Merkel, A.; Knowles, D.G.; et al. The GENCODE v7 catalog of human long noncoding RNAs: Analysis of their gene structure, evolution, and expression. Genome Res. 2012, 22, 1775-1789. [CrossRef] [PubMed]

27. Djebali, S.; Davis, C.A.; Merkel, A.; Dobin, A.; Lassmann, T.; Mortazavi, A.; Tanzer, A.; Lagarde, J.; Lin, W.; Schlesinger, F.; et al. Landscape of transcription in human cells. Nature 2012, 489, 101-108. [CrossRef] [PubMed]

28. Guttman, M.; Amit, I.; Garber, M.; French, C.; Lin, M.F.; Feldser, D.; Huarte, M.; Zuk, O.; Carey, B.W.; Cassady, J.P.; et al. Chromatin signature reveals over a thousand highly conserved large non-coding RNAs in mammals. Nature 2009, 458, 223-227. [CrossRef] [PubMed]

29. Clark, M.B.; Mercer, T.R.; Bussotti, G.; Leonardi, T.; Haynes, K.R.; Crawford, J.; Brunck, M.E.; Cao, K.A.; Thomas, G.P.; Chen, W.Y.; et al. Quantitative gene profiling of long noncoding RNAs with targeted RNA sequencing. Nat. Methods 2015, 12, 339-342. [CrossRef] [PubMed]

30. Quinn, J.J.; Chang, H.Y. Unique features of long non-coding RNA biogenesis and function. Nat. Rev. Genet. 2015, 17, 47-62. [CrossRef] [PubMed]

31. Mercer, T.R.; Mattick, J.S. Structure and function of long noncoding RNAs in epigenetic regulation. Nat. Struct. Mol. Biol. 2013, 20, 300-307. [CrossRef] [PubMed]

32. Ma, L.; Bajic, V.B.; Zhang, Z. On the classification of long non-coding RNAs. RNA Biol. 2013, 10, $925-933$. [CrossRef] [PubMed]

33. Cabili, M.N.; Dunagin, M.C.; McClanahan, P.D.; Biaesch, A.; Padovan-Merhar, O.; Regev, A.; Rinn, J.L.; Raj, A. Localization and abundance analysis of human lncRNAs at single-cell and single-molecule resolution. Genome Biol. 2015, 16. [CrossRef] [PubMed]

34. Harries, L.W. Long non-coding RNAs and human disease. Biochem. Soc. Trans. 2012, 40, 902-906. [CrossRef] [PubMed]

35. Prensner, J.R.; Chinnaiyan, A.M. The emergence of lncRNAs in cancer biology. Cancer Discov. 2011, 1, 391-407. [CrossRef] [PubMed]

36. Gong, C.; Maquat, L.E. lncRNAs transactivate STAU1-mediated mRNA decay by duplexing with $3^{\prime}$ UTRs via Alu elements. Nature 2011, 470, 284-288. [CrossRef] [PubMed]

37. Yoon, J.H.; Abdelmohsen, K.; Srikantan, S.; Yang, X.; Martindale, J.L.; De, S.; Huarte, M.; Zhan, M.; Becker, K.G.; Gorospe, M. LincRNA-p21 suppresses target mRNA translation. Mol. Cell 2012, 47, 648-655.

38. Nagano, T.; Fraser, P. No-nonsense functions for long noncoding RNAs. Cell 2011, 145, 178-181. [CrossRef] [PubMed]

39. Wang, K.C.; Chang, H.Y. Molecular mechanisms of long noncoding RNAs. Mol. Cell 2011, 43, 904-914. [CrossRef] [PubMed]

40. Chu, C.; Qu, K.; Zhong, F.L.; Artandi, S.E.; Chang, H.Y. Genomic maps of long noncoding RNA occupancy reveal principles of RNA-chromatin interactions. Mol. Cell 2011, 44, 667-678. [CrossRef] [PubMed] 
41. Simon, M.D.; Wang, C.I.; Kharchenko, P.V.; West, J.A.; Chapman, B.A.; Alekseyenko, A.A.; Borowsky, M.L.; Kuroda, M.I.; Kingston, R.E. The genomic binding sites of a noncoding RNA. Proc. Natl. Acad. Sci. USA 2011, 108, 20497-20502. [CrossRef] [PubMed]

42. Khalil, A.M.; Guttman, M.; Huarte, M.; Garber, M.; Raj, A.; Rivea Morales, D.; Thomas, K.; Presser, A.; Bernstein, B.E.; van Oudenaarden, A.; et al. Many human large intergenic noncoding RNAs associate with chromatin-modifying complexes and affect gene expression. Proc. Natl. Acad. Sci. USA 2009, 106, 11667-11672. [CrossRef] [PubMed]

43. Yoon, J.H.; Abdelmohsen, K.; Kim, J.; Yang, X.; Martindale, J.L.; Tominaga-Yamanaka, K.; White, E.J.; Orjalo, A.V.; Rinn, J.L.; Kreft, S.G.; et al. Scaffold function of long non-coding RNA HOTAIR in protein ubiquitination. Nat. Commun. 2013, 4. [CrossRef] [PubMed]

44. Tsai, M.C.; Manor, O.; Wan, Y.; Mosammaparast, N.; Wang, J.K.; Lan, F.; Shi, Y.; Segal, E.; Chang, H.Y. Long noncoding RNA as modular scaffold of histone modification complexes. Science 2010, 329, 689-693. [CrossRef] [PubMed]

45. Tripathi, V.; Ellis, J.D.; Shen, Z.; Song, D.Y.; Pan, Q.; Watt, A.T.; Freier, S.M.; Bennett, C.F.; Sharma, A.; Bubulya, P.A.; et al. The nuclear-retained noncoding RNA MALAT1 regulates alternative splicing by modulating SR splicing factor phosphorylation. Mol. Cell 2010, 39, 925-938. [CrossRef] [PubMed]

46. Malek, E.; Jagannathan, S.; Driscoll, J.J. Correlation of long non-coding RNA expression with metastasis, drug resistance and clinical outcome in cancer. Oncotarget 2014, 5, 8027-8038. [CrossRef] [PubMed]

47. Deng, R.; Liu, B.; Wang, Y.; Yan, F.; Hu, S.; Wang, H.; Wang, T.; Li, B.; Deng, X.; Xiang, S.; et al. High Expression of the Newly Found Long Noncoding RNA Z38 Promotes Cell Proliferation and Oncogenic Activity in Breast Cancer. J. Cancer 2016, 7, 576-586. [CrossRef] [PubMed]

48. Xue, S.; Li, Q.W.; Che, J.P.; Guo, Y.; Yang, F.Q.; Zheng, J.H. Decreased expression of long non-coding RNA NBAT-1 is associated with poor prognosis in patients with clear cell renal cell carcinoma. Int. J. Clin. Exp. Pathol. 2015, 8, 3765-3774. [PubMed]

49. Zhang, Y.; Wang, T.; Huang, H.Q.; Li, W.; Cheng, X.L.; Yang, J. Human MALAT-1 long non-coding RNA is overexpressed in cervical cancer metastasis and promotes cell proliferation, invasion and migration. J. BUON 2015, 20, 1497-1503. [PubMed]

50. Chang, L.; Li, C.; Lan, T.; Wu, L.; Yuan, Y.; Liu, Q.; Liu, Z. Decreased expression of long non-coding RNA GAS5 indicates a poor prognosis and promotes cell proliferation and invasion in hepatocellular carcinoma by regulating vimentin. Mol. Med. Rep. 2016, 13, 1541-1550. [CrossRef] [PubMed]

51. Cheetham, S.W.; Gruhl, F.; Mattick, J.S.; Dinger, M.E. Long noncoding RNAs and the genetics of cancer. Br. J. Cancer 2013, 108, 2419-2425. [CrossRef] [PubMed]

52. Zhang, X.F.; Liu, T.; Li, Y.; Li, S. Overexpression of long non-coding RNA CCAT1 is a novel biomarker of poor prognosis in patients with breast cancer. Int. J. Clin. Exp. Pathol. 2015, 8, 9440-9445. [PubMed]

53. Wang, C.Y.; Hua, L.; Yao, K.H.; Chen, J.T.; Zhang, J.J.; Hu, J.H. Long non-coding RNA CCAT2 is up-regulated in gastric cancer and associated with poor prognosis. Int. J. Clin. Exp. Pathol. 2015, 8, 779-785. [PubMed]

54. Sang, Y.; Tang, J.; Li, S.; Li, L.; Tang, X.; Cheng, C.; Luo, Y.; Qian, X.; Deng, L.M.; Liu, L.; et al. IncRNA PANDAR regulates the G1/S transition of breast cancer cells by suppressing p16(INK4A) expression. Sci. Rep. 2016, 6. [CrossRef] [PubMed]

55. Seles, M.; Hutterer, G.C.; Kiesslich, T.; Pummer, K.; Berindan-Neagoe, I.; Perakis, S.; Schwarzenbacher, D.; Stotz, M.; Gerger, A.; Pichler, M. Current Insights into Long Non-Coding RNAs in Renal Cell Carcinoma. Int. J. Mol. Sci. 2016, 17, 573. [CrossRef] [PubMed]

56. Smolle, M.A.; Bullock, M.D.; Ling, H.; Pichler, M.; Haybaeck, J. Long Non-Coding RNAs in Endometrial Carcinoma. Int. J. Mol. Sci. 2015, 16, 26463-26472. [CrossRef] [PubMed]

57. Smolle, M.; Uranitsch, S.; Gerger, A.; Pichler, M.; Haybaeck, J. Current status of long non-coding RNAs in human cancer with specific focus on colorectal cancer. Int. J. Mol. Sci. 2014, 15, 13993-14013. [CrossRef] [PubMed]

58. Ding, X.; Zhu, L.; Ji, T.; Zhang, X.; Wang, F.; Gan, S.; Zhao, M.; Yang, H. Long intergenic non-coding RNAs (lncRNAs) identified by RNA-seq in breast cancer. PLoS ONE 2014, 9, e103270.

59. Xu, N.; Wang, F.; Lv, M.; Cheng, L. Microarray expression profile analysis of long non-coding RNAs in human breast cancer: A study of Chinese women. Biomed. Pharmacother. 2015, 69, 221-227. [CrossRef] [PubMed] 
60. Reiche, K.; Kasack, K.; Schreiber, S.; Luders, T.; Due, E.U.; Naume, B.; Riis, M.; Kristensen, V.N.; Horn, F.; Borresen-Dale, A.L.; et al. Long non-coding RNAs differentially expressed between normal versus primary breast tumor tissues disclose converse changes to breast cancer-related protein-coding genes. PLoS ONE 2014, 9, e106076. [CrossRef] [PubMed]

61. Yang, F.; Lyu, S.; Dong, S.; Liu, Y.; Zhang, X.; Wang, O. Expression profile analysis of long noncoding RNA in HER-2-enriched subtype breast cancer by next-generation sequencing and bioinformatics. Oncol. Targets Ther. 2016, 9, 761-772. [CrossRef] [PubMed]

62. Jonsson, P.; Coarfa, C.; Mesmar, F.; Raz, T.; Rajapakshe, K.; Thompson, J.F.; Gunaratne, P.H.; Williams, C. Single-Molecule Sequencing Reveals Estrogen-Regulated Clinically Relevant lncRNAs in Breast Cancer. Mol. Endocrinol. 2015, 29, 1634-1645. [CrossRef] [PubMed]

63. Miano, V.; Ferrero, G.; Reineri, S.; Caizzi, L.; Annaratone, L.; Ricci, L.; Cutrupi, S.; Castellano, I.; Cordero, F.; de Bortoli, M. Luminal long non-coding RNAs regulated by estrogen receptor alpha in a ligand-independent manner show functional roles in breast cancer. Oncotarget 2016, 7, 3201-3216. [PubMed]

64. Su, X.; Malouf, G.G.; Chen, Y.; Zhang, J.; Yao, H.; Valero, V.; Weinstein, J.N.; Spano, J.P.; Meric-Bernstam, F.; Khayat, D.; et al. Comprehensive analysis of long non-coding RNAs in human breast cancer clinical subtypes. Oncotarget 2014, 5, 9864-9876. [CrossRef] [PubMed]

65. Liu, Y.R.; Jiang, Y.Z.; Xu, X.E.; Yu, K.D.; Jin, X.; Hu, X.; Zuo, W.J.; Hao, S.; Wu, J.; Liu, G.Y.; et al. Comprehensive transcriptome analysis identifies novel molecular subtypes and subtype-specific RNAs of triple-negative breast cancer. Breast Cancer Res. 2016, 18. [CrossRef] [PubMed]

66. Liu, H.; Li, J.; Koirala, P.; Ding, X.; Chen, B.; Wang, Y.; Wang, Z.; Wang, C.; Zhang, X.; Mo, Y.Y. Long non-coding RNAs as prognostic markers in human breast cancer. Oncotarget 2016, 7, 20584-20596. [CrossRef] [PubMed]

67. Jiang, Y.Z.; Liu, Y.R.; Xu, X.E.; Jin, X.; Hu, X.; Yu, K.D.; Shao, Z.M. Transcriptome Analysis of Triple-Negative Breast Cancer Reveals an Integrated mRNA-lncRNA Signature with Predictive and Prognostic Value. Cancer Res. 2016, 76, 2105-2114. [CrossRef] [PubMed]

68. Zemel, S.; Bartolomei, M.S.; Tilghman, S.M. Physical linkage of two mammalian imprinted genes, H19 and insulin-like growth factor 2. Nat. Genet. 1992, 2, 61-65. [CrossRef] [PubMed]

69. Giannoukakis, N.; Deal, C.; Paquette, J.; Goodyer, C.G.; Polychronakos, C. Parental genomic imprinting of the human IGF2 gene. Nat. Genet. 1993, 4, 98-101. [CrossRef] [PubMed]

70. Zhang, Y.; Tycko, B. Monoallelic expression of the human H19 gene. Nat. Genet. 1992, 1, 40-44. [CrossRef] [PubMed]

71. Li, Y.M.; Franklin, G.; Cui, H.M.; Svensson, K.; He, X.B.; Adam, G.; Ohlsson, R.; Pfeifer, S. The H19 transcript is associated with polysomes and may regulate IGF2 expression in trans. J. Biol. Chem. 1998, 273, 28247-28252. [CrossRef] [PubMed]

72. Berteaux, N.; Lottin, S.; Monte, D.; Pinte, S.; Quatannens, B.; Coll, J.; Hondermarck, H.; Curgy, J.J.; Dugimont, T.; Adriaenssens, E. H19 mRNA-like noncoding RNA promotes breast cancer cell proliferation through positive control by E2F1. J. Biol. Chem. 2005, 280, 29625-29636. [CrossRef] [PubMed]

73. Vennin, C.; Spruyt, N.; Dahmani, F.; Julien, S.; Bertucci, F.; Finetti, P.; Chassat, T.; Bourette, R.P.; le Bourhis, X.; Adriaenssens, E. H19 non coding RNA-derived miR-675 enhances tumorigenesis and metastasis of breast cancer cells by downregulating c-Cbl and Cbl-b. Oncotarget 2015, 6, 29209-29223. [PubMed]

74. Doucrasy, S.; Coll, J.; Barrois, M.; Joubel, A.; Prost, S.; Dozier, C.; Stehelin, D.; Riou, G. Expression of the human fetal bac h19 gene in invasive cancers. Int. J. Oncol. 1993, 2, 753-758. [CrossRef] [PubMed]

75. Elkin, M.; Shevelev, A.; Schulze, E.; Tykocinsky, M.; Cooper, M.; Ariel, I.; Pode, D.; Kopf, E.; de Groot, N.; Hochberg, A. The expression of the imprinted H19 and IGF-2 genes in human bladder carcinoma. FEBS Lett. 1995, 374, 57-61. [CrossRef]

76. Kondo, M.; Suzuki, H.; Ueda, R.; Osada, H.; Takagi, K.; Takahashi, T. Frequent loss of imprinting of the H19 gene is often associated with its overexpression in human lung cancers. Oncogene 1995, 10, 1193-1198. [PubMed]

77. Hibi, K.; Nakamura, H.; Hirai, A.; Fujikake, Y.; Kasai, Y.; Akiyama, S.; Ito, K.; Takagi, H. Loss of H19 imprinting in esophageal cancer. Cancer Res. 1996, 56, 480-482. [PubMed]

78. Douc-Rasy, S.; Barrois, M.; Fogel, S.; Ahomadegbe, J.C.; Stehelin, D.; Coll, J.; Riou, G. High incidence of loss of heterozygosity and abnormal imprinting of H19 and IGF2 genes in invasive cervical carcinomas. Uncoupling of H19 and IGF2 expression and biallelic hypomethylation of H19. Oncogene 1996, 12, 423-430. [PubMed] 
79. Adriaenssens, E.; Dumont, L.; Lottin, S.; Bolle, D.; Lepretre, A.; Delobelle, A.; Bouali, F.; Dugimont, T.; Coll, J.; Curgy, J.J. H19 overexpression in breast adenocarcinoma stromal cells is associated with tumor values and steroid receptor status but independent of p53 and Ki-67 expression. Am. J. Pathol. 1998, 153, 1597-1607. [CrossRef]

80. Dugimont, T.; Curgy, J.J.; Wernert, N.; Delobelle, A.; Raes, M.B.; Joubel, A.; Stehelin, D.; Coll, J. The H19 gene is expressed within both epithelial and stromal components of human invasive adenocarcinomas. Biol. Cell 1995, 85, 117-124. [CrossRef]

81. Wang, Q.; Zhang, J.; Liu, Y.; Zhang, W.; Zhou, J.; Duan, R.; Pu, P.; Kang, C.; Han, L. A novel cell cycle-associated lncRNA, HOXA11-AS, is transcribed from the 5-prime end of the HOXA transcript and is a biomarker of progression in Glioma. Cancer Lett. 2016, 373, 251-259. [CrossRef] [PubMed]

82. Han, D.; Gao, X.; Wang, M.; Qiao, Y.; Xu, Y.; Yang, J.; Dong, N.; He, J.; Sun, Q.; Lv, G.; et al. Long noncoding RNA H19 indicates a poor prognosis of colorectal cancer and promotes tumor growth by recruiting and binding to eIF4A3. Oncotarget 2016, 7, 22159-22173. [PubMed]

83. Chen, J.S.; Wang, Y.F.; Zhang, X.Q.; Lv, J.M.; Li, Y.; Liu, X.X.; Xu, T.P. H19 serves as a diagnostic biomarker and up-regulation of $\mathrm{H} 19$ expression contributes to poor prognosis in patients with gastric cancer. Neoplasma 2016, 63, 223-230. [CrossRef] [PubMed]

84. Matouk, I.J.; Raveh, E.; Abu-lail, R.; Mezan, S.; Gilon, M.; Gershtain, E.; Birman, T.; Gallula, J.; Schneider, T.; Barkali, M.; et al. Oncofetal H19 RNA promotes tumor metastasis. Biochim. Biophys. Acta 2014, 1843, 1414-1426. [CrossRef] [PubMed]

85. Barsyte-Lovejoy, D.; Lau, S.K.; Boutros, P.C.; Khosravi, F.; Jurisica, I.; Andrulis, I.L.; Tsao, M.S.; Penn, L.Z. The c-Myc oncogene directly induces the H19 noncoding RNA by allele-specific binding to potentiate tumorigenesis. Cancer Res. 2006, 66, 5330-5337. [CrossRef] [PubMed]

86. Kallen, A.N.; Zhou, X.B.; Xu, J.; Qiao, C.; Ma, J.; Yan, L.; Lu, L.; Liu, C.; Yi, J.S.; Zhang, H.; et al. The imprinted H19 lncRNA antagonizes let-7 microRNAs. Mol. Cell 2013, 52, 101-112. [CrossRef] [PubMed]

87. Cai, X.; Cullen, B.R. The imprinted H19 noncoding RNA is a primary microRNA precursor. RNA 2007, 13, 313-316. [CrossRef] [PubMed]

88. Raveh, E.; Matouk, I.J.; Gilon, M.; Hochberg, A. The H19 Long non-coding RNA in cancer initiation, progression and metastasis-A proposed unifying theory. Mol. Cancer 2015, 14, 184. [CrossRef] [PubMed]

89. Hernandez, J.M.; Elahi, A.; Clark, C.W.; Wang, J.; Humphries, L.A.; Centeno, B.; Bloom, G.; Fuchs, B.C.; Yeatman, T.; Shibata, D. miR-675 mediates downregulation of Twist1 and Rb in AFP-secreting hepatocellular carcinoma. Ann. Surg. Oncol. 2013, 20 (Suppl. S3), S625-S635. [CrossRef] [PubMed]

90. Lottin, S.; Adriaenssens, E.; Dupressoir, T.; Berteaux, N.; Montpellier, C.; Coll, J.; Dugimont, T.; Curgy, J.J. Overexpression of an ectopic H19 gene enhances the tumorigenic properties of breast cancer cells. Carcinogenesis 2002, 23, 1885-1895. [CrossRef] [PubMed]

91. Zhang, J.; Zhang, P.; Wang, L.; Piao, H.L.; Ma, L. Long non-coding RNA HOTAIR in carcinogenesis and metastasis. Acta Biochim. Biophys. Sin. 2014, 46, 1-5. [CrossRef] [PubMed]

92. Rinn, J.L.; Kertesz, M.; Wang, J.K.; Squazzo, S.L.; Xu, X.; Brugmann, S.A.; Goodnough, L.H.; Helms, J.A.; Farnham, P.J.; Segal, E.; et al. Functional demarcation of active and silent chromatin domains in human HOX loci by noncoding RNAs. Cell 2007, 129, 1311-1323. [CrossRef] [PubMed]

93. Hajjari, M.; Salavaty, A. HOTAIR: An oncogenic long non-coding RNA in different cancers. Cancer Biol. Med. 2015, 12, 1-9. [PubMed]

94. Gupta, R.A.; Shah, N.; Wang, K.C.; Kim, J.; Horlings, H.M.; Wong, D.J.; Tsai, M.C.; Hung, T.; Argani, P.; Rinn, J.L.; et al. Long non-coding RNA HOTAIR reprograms chromatin state to promote cancer metastasis. Nature 2010, 464, 1071-1076. [CrossRef] [PubMed]

95. Davidovich, C.; Zheng, L.; Goodrich, K.J.; Cech, T.R. Promiscuous RNA binding by Polycomb repressive complex 2. Nat. Struct. Mol. Biol. 2013, 20, 1250-1257. [CrossRef] [PubMed]

96. Wu, Y.; Zhang, L.; Wang, Y.; Li, H.; Ren, X.; Wei, F.; Yu, W.; Wang, X.; Zhang, L.; Yu, J.; et al. Long noncoding RNA HOTAIR involvement in cancer. Tumour Biol. 2014, 35, 9531-9538. [CrossRef] [PubMed]

97. Li, L.; Liu, B.; Wapinski, O.L.; Tsai, M.C.; Qu, K.; Zhang, J.; Carlson, J.C.; Lin, M.; Fang, F.; Gupta, R.A.; et al. Targeted disruption of Hotair leads to homeotic transformation and gene derepression. Cell Rep. 2013, 5 , 3-12. [CrossRef] [PubMed]

98. Bhan, A.; Hussain, I.; Ansari, K.I.; Kasiri, S.; Bashyal, A.; Mandal, S.S. Antisense transcript long noncoding RNA (lncRNA) HOTAIR is transcriptionally induced by estradiol. J. Mol. Biol. 2013, 425, 3707-3722. [CrossRef] [PubMed] 
99. Bhan, A.; Mandal, S.S. Estradiol-Induced Transcriptional Regulation of Long Non-Coding RNA, HOTAIR. Methods Mol. Biol. 2016, 1366, 395-412. [PubMed]

100. Tao, S.; He, H.; Chen, Q. Estradiol induces HOTAIR levels via GPER-mediated miR-148a inhibition in breast cancer. J. Transl. Med. 2015, 13. [CrossRef] [PubMed]

101. Padua Alves, C.; Fonseca, A.S.; Muys, B.R.; de Barros, E.L.B.R.; Burger, M.C.; de Souza, J.E.; Valente, V.; Zago, M.A.; Silva, W.A., Jr. Brief report: The lincRNA Hotair is required for epithelial-to-mesenchymal transition and stemness maintenance of cancer cell lines. Stem Cells 2013, 31, 2827-2832. [CrossRef] [PubMed]

102. Zhang, H.; Cai, K.; Wang, J.; Wang, X.; Cheng, K.; Shi, F.; Jiang, L.; Zhang, Y.; Dou, J. MiR-7, inhibited indirectly by lincRNA HOTAIR, directly inhibits SETDB1 and reverses the EMT of breast cancer stem cells by downregulating the STAT3 pathway. Stem Cells 2014, 32, 2858-2868. [CrossRef] [PubMed]

103. Ren, D.; Li, H.; Li, R.; Sun, J.; Guo, P.; Han, H.; Yang, Y.; Li, J. Novel insight into MALAT-1 in cancer: Therapeutic targets and clinical applications. Oncol. Lett. 2016, 11, 1621-1630. [CrossRef] [PubMed]

104. Gutschner, T.; Hammerle, M.; Diederichs, S. MALAT1-A paradigm for long noncoding RNA function in cancer. J. Mol. Med. 2013, 91, 791-801. [CrossRef] [PubMed]

105. Schmidt, L.H.; Spieker, T.; Koschmieder, S.; Schaffers, S.; Humberg, J.; Jungen, D.; Bulk, E.; Hascher, A.; Wittmer, D.; Marra, A.; et al. The long noncoding MALAT-1 RNA indicates a poor prognosis in non-small cell lung cancer and induces migration and tumor growth. J. Thorac. Oncol. 2011, 6, 1984-1992. [CrossRef] [PubMed]

106. Wu, X.S.; Wang, X.A.; Wu, W.G.; Hu, Y.P.; Li, M.L.; Ding, Q.; Weng, H.; Shu, Y.J.; Liu, T.Y.; Jiang, L.; et al. MALAT1 promotes the proliferation and metastasis of gallbladder cancer cells by activating the ERK/MAPK pathway. Cancer Biol. Ther. 2014, 15, 806-814. [CrossRef] [PubMed]

107. Tripathi, V.; Shen, Z.; Chakraborty, A.; Giri, S.; Freier, S.M.; Wu, X.; Zhang, Y.; Gorospe, M.; Prasanth, S.G.; Lal, A.; et al. Long noncoding RNA MALAT1 controls cell cycle progression by regulating the expression of oncogenic transcription factor B-MYB. PLoS Genet. 2013, 9, e1003368. [CrossRef] [PubMed]

108. Ying, L.; Chen, Q.; Wang, Y.; Zhou, Z.; Huang, Y.; Qiu, F. Upregulated MALAT-1 contributes to bladder cancer cell migration by inducing epithelial-to-mesenchymal transition. Mol. Biosyst. 2012, 8, 2289-2294. [CrossRef] [PubMed]

109. Li, G.; Zou, L.; Xie, W.; Wen, S.; Xie, Q.; Gao, Y.; Xu, C.; Xu, H.; Liu, S.; Wang, S.; et al. The effects of NONRATT021972 IncRNA siRNA on PC12 neuronal injury mediated by P2X7 receptor after exposure to oxygen-glucose deprivation. Purinergic Signal. 2016. [CrossRef] [PubMed]

110. Wang, Y.; Xue, D.; Li, Y.; Pan, X.; Zhang, X.; Kuang, B.; Zhou, M.; Li, X.; Xiong, W.; Li, G.; et al. The Long Noncoding RNA MALAT-1 is A Novel Biomarker in Various Cancers: A Meta-analysis Based on the GEO Database and Literature. J. Cancer 2016, 7, 991-1001. [CrossRef] [PubMed]

111. Meseure, D.; Vacher, S.; Lallemand, F.; Alsibai, K.D.; Hatem, R.; Chemlali, W.; Nicolas, A.; De Koning, L.; Pasmant, E.; Callens, C.; et al. Prognostic value of a newly identified MALAT1 alternatively spliced transcript in breast cancer. Br. J. Cancer 2016, 114, 1395-1404. [CrossRef] [PubMed]

112. Jadaliha, M.; Zong, X.; Malakar, P.; Ray, T.; Singh, D.K.; Freier, S.M.; Jensen, T.; Prasanth, S.G.; Karni, R.; Ray, P.S.; et al. Functional and prognostic significance of long non-coding RNA MALAT1 as a metastasis driver in ER negative lymph node negative breast cancer. Oncotarget 2016. [CrossRef] [PubMed]

113. Spatz, A.; Borg, C.; Feunteun, J. X-chromosome genetics and human cancer. Nat. Rev. Cancer 2004, 4, 617-629. [CrossRef] [PubMed]

114. Weakley, S.M.; Wang, H.; Yao, Q.; Chen, C. Expression and function of a large non-coding RNA gene XIST in human cancer. World J. Surg. 2011, 35, 1751-1756. [CrossRef] [PubMed]

115. Kawakami, T.; Zhang, C.; Taniguchi, T.; Kim, C.J.; Okada, Y.; Sugihara, H.; Hattori, T.; Reeve, A.E.; Ogawa, O.; Okamoto, K. Characterization of loss-of-inactive $\mathrm{X}$ in Klinefelter syndrome and female-derived cancer cells. Oncogene 2004, 23, 6163-6169. [CrossRef] [PubMed]

116. Sirchia, S.M.; Tabano, S.; Monti, L.; Recalcati, M.P.; Gariboldi, M.; Grati, F.R.; Porta, G.; Finelli, P.; Radice, P.; Miozzo, M. Misbehaviour of XIST RNA in breast cancer cells. PLoS ONE 2009, 4, e5559. [CrossRef] [PubMed]

117. Pickard, M.R.; Williams, G.T. Molecular and Cellular Mechanisms of Action of Tumour Suppressor GAS5 lncRNA. Genes 2015, 6, 484-499. [CrossRef] [PubMed]

118. Pickard, M.R.; Williams, G.T. Regulation of apoptosis by long non-coding RNA GAS5 in breast cancer cells: Implications for chemotherapy. Breast Cancer Res. Treat. 2014, 145, 359-370. [CrossRef] [PubMed] 
119. Mourtada-Maarabouni, M.; Pickard, M.R.; Hedge, V.L.; Farzaneh, F.; Williams, G.T. GAS5, a non-proteincoding RNA, controls apoptosis and is downregulated in breast cancer. Oncogene 2009, 28, 195-208. [CrossRef] [PubMed]

120. Pickard, M.R.; Mourtada-Maarabouni, M.; Williams, G.T. Long non-coding RNA GAS5 regulates apoptosis in prostate cancer cell lines. Biochim. Biophys. Acta 2013, 1832, 1613-1623. [CrossRef] [PubMed]

121. Lu, X.; Fang, Y.; Wang, Z.; Xie, J.; Zhan, Q.; Deng, X.; Chen, H.; Jin, J.; Peng, C.; Li, H.; et al. Downregulation of gas5 increases pancreatic cancer cell proliferation by regulating CDK6. Cell Tissue Res. 2013, 354, 891-896. [CrossRef] [PubMed]

122. Pickard, M.R.; Williams, G.T. The hormone response element mimic sequence of GAS5 lncRNA is sufficient to induce apoptosis in breast cancer cells. Oncotarget 2016, 7, 10104-10116. [PubMed]

123. Li, W.; Zhai, L.; Wang, H.; Liu, C.; Zhang, J.; Chen, W.; Wei, Q. Downregulation of lncRNA GAS5 causes trastuzumab resistance in breast cancer. Oncotarget 2016, 7, 27778-27786. [CrossRef] [PubMed]

124. Puvvula, P.K.; Desetty, R.D.; Pineau, P.; Marchio, A.; Moon, A.; Dejean, A.; Bischof, O. Long noncoding RNA PANDA and scaffold-attachment-factor SAFA control senescence entry and exit. Nat Commun. 2014, 5. [CrossRef] [PubMed]

125. Wright, M.W. A short guide to long non-coding RNA gene nomenclature. Hum. Genom. 2014, 8. [CrossRef] [PubMed]

126. Ning, S.; Gao, Y.; Wang, P.; Li, X.; Zhi, H.; Zhang, Y.; Liu, Y.; Zhang, J.; Guo, M.; Han, D.; Li, X. Construction of a lncRNA-mediated feed-forward loop network reveals global topological features and prognostic motifs in human cancers. Oncotarget 2016. [CrossRef] [PubMed]

127. Han, L.; Zhang, E.B.; Yin, D.D.; Kong, R.; Xu, T.P.; Chen, W.M.; Xia, R.; Shu, Y.Q.; De, W. Low expression of long noncoding RNA PANDAR predicts a poor prognosis of non-small cell lung cancer and affects cell apoptosis by regulating Bcl-2. Cell Death Dis. 2015, 6. [CrossRef] [PubMed]

128. Ma, P.; Xu, T.; Huang, M.; Shu, Y. Increased expression of lncRNA PANDAR predicts a poor prognosis in gastric cancer. Biomed. Pharmacother. 2016, 78, 172-176. [CrossRef] [PubMed]

129. Peng, W.; Fan, H. Long non-coding RNA PANDAR correlates with poor prognosis and promotes tumorigenesis in hepatocellular carcinoma. Biomed. Pharmacother. 2015, 72, 113-118. [CrossRef] [PubMed]

130. Kelson, M.; Farebrother, M. The effect of inaccuracies in death certification and coding practices in the European Economic Community (EEC) on international cancer mortality statistics. Int. J. Epidemiol. 1987, 16, 411-414. [CrossRef] [PubMed]

131. Yang, F.; Xue, X.; Bi, J.; Zheng, L.; Zhi, K.; Gu, Y.; Fang, G. Long noncoding RNA CCAT1, which could be activated by c-Myc, promotes the progression of gastric carcinoma. J. Cancer Res. Clin. Oncol. 2013, 139, 437-445. [CrossRef] [PubMed]

132. Ye, Z.; Zhou, M.; Tian, B.; Wu, B.; Li, J. Expression of lncRNA-CCAT1, E-cadherin and N-cadherin in colorectal cancer and its clinical significance. Int. J. Clin. Exp. Med. 2015, 8, 3707-3715. [PubMed]

133. Zhu, H.; Zhou, X.; Chang, H.; Li, H.; Liu, F.; Ma, C.; Lu, J. CCAT1 promotes hepatocellular carcinoma cell proliferation and invasion. Int. J. Clin. Exp. Pathol. 2015, 8, 5427-5434. [PubMed]

134. Deng, L.; Yang, S.B.; Xu, F.F.; Zhang, J.H. Long noncoding RNA CCAT1 promotes hepatocellular carcinoma progression by functioning as let-7 sponge. J. Exp. Clin. Cancer Res. 2015, 34. [CrossRef] [PubMed]

135. Ma, M.Z.; Chu, B.F.; Zhang, Y.; Weng, M.Z.; Qin, Y.Y.; Gong, W.; Quan, Z.W. Long non-coding RNA CCAT1 promotes gallbladder cancer development via negative modulation of miRNA-218-5p. Cell Death Dis. 2015, 6. [CrossRef] [PubMed]

136. Dang, C.V.; O’Donnell, K.A.; Zeller, K.I.; Nguyen, T.; Osthus, R.C.; Li, F. The c-Myc target gene network. Semin. Cancer Biol. 2006, 16, 253-264. [CrossRef] [PubMed]

137. Zhu, H.Q.; Zhou, X.; Chang, H.; Li, H.G.; Liu, F.F.; Ma, C.Q.; Lu, J. Aberrant Expression of CCAT1 Regulated by c-Myc Predicts the Prognosis of Hepatocellular Carcinoma. Asian Pac. J. Cancer Prev. 2015, 16, 5181-5185. [CrossRef] [PubMed]

138. Ling, H.; Spizzo, R.; Atlasi, Y.; Nicoloso, M.; Shimizu, M.; Redis, R.S.; Nishida, N.; Gafa, R.; Song, J.; Guo, Z.; et al. CCAT2, a novel noncoding RNA mapping to 8q24, underlies metastatic progression and chromosomal instability in colon cancer. Genome Res. 2013, 23, 1446-1461. [CrossRef] [PubMed]

139. Cai, Y.; He, J.; Zhang, D. Long noncoding RNA CCAT2 promotes breast tumor growth by regulating the Wnt signaling pathway. Oncol. Targets Ther. 2015, 8, 2657-2664. 
140. Chen, X.; Liu, L.; Zhu, W. Up-regulation of long non-coding RNA CCAT2 correlates with tumor metastasis and poor prognosis in cervical squamous cell cancer patients. Int. J. Clin. Exp. Pathol. 2015, 8, 13261-13266. [PubMed]

141. Qiu, M.; Xu, Y.; Yang, X.; Wang, J.; Hu, J.; Xu, L.; Yin, R. CCAT2 is a lung adenocarcinoma-specific long non-coding RNA and promotes invasion of non-small cell lung cancer. Tumour Biol. 2014, 35, 5375-5380. [CrossRef] [PubMed]

142. Redis, R.S.; Sieuwerts, A.M.; Look, M.P.; Tudoran, O.; Ivan, C.; Spizzo, R.; Zhang, X.; de Weerd, V.; Shimizu, M.; Ling, H.; et al. CCAT2, a novel long non-coding RNA in breast cancer: Expression study and clinical correlations. Oncotarget 2013, 4, 1748-1762. [CrossRef] [PubMed]

143. Zhang, X.; Xu, Y.; He, C.; Guo, X.; Zhang, J.; Zhang, L.; Kong, M.; Chen, B.; Zhu, C. Elevated expression of CCAT2 is associated with poor prognosis in esophageal squamous cell carcinoma. J. Surg. Oncol. 2015, 111, 834-839. [CrossRef] [PubMed]

144. Redis, R.S.; Vela, L.E.; Lu, W.; Ferreira de Oliveira, J.; Ivan, C.; Rodriguez-Aguayo, C.; Adamoski, D.; Pasculli, B.; Taguchi, A.; Chen, Y.; et al. Allele-Specific Reprogramming of Cancer Metabolism by the Long Non-coding RNA CCAT2. Mol. Cell 2016, 61, 520-534. [CrossRef] [PubMed]

145. Wang, F.; Li, X.; Xie, X.; Zhao, L.; Chen, W. UCA1, a non-protein-coding RNA up-regulated in bladder carcinoma and embryo, influencing cell growth and promoting invasion. FEBS Lett. 2008, 582, 1919-1927. [CrossRef] [PubMed]

146. Wang, X.S.; Zhang, Z.; Wang, H.C.; Cai, J.L.; Xu, Q.W.; Li, M.Q.; Chen, Y.C.; Qian, X.P.; Lu, T.J.; Yu, L.Z.; et al. Rapid identification of UCA1 as a very sensitive and specific unique marker for human bladder carcinoma. Clin. Cancer Res. 2006, 12, 4851-4858. [CrossRef] [PubMed]

147. Tuo, Y.L.; Li, X.M.; Luo, J. Long noncoding RNA UCA1 modulates breast cancer cell growth and apoptosis through decreasing tumor suppressive miR-143. Eur. Rev. Med. Pharmacol. Sci. 2015, 19, 3403-3411. [PubMed]

148. Han, Y.; Yang, Y.N.; Yuan, H.H.; Zhang, T.T.; Sui, H.; Wei, X.L.; Liu, L.; Huang, P.; Zhang, W.J.; Bai, Y.X. UCA1, a long non-coding RNA up-regulated in colorectal cancer influences cell proliferation, apoptosis and cell cycle distribution. Pathology 2014, 46, 396-401. [CrossRef] [PubMed]

149. Zheng, Q.; Wu, F.; Dai, W.Y.; Zheng, D.C.; Zheng, C.; Ye, H.; Zhou, B.; Chen, J.J.; Chen, P. Aberrant expression of UCA1 in gastric cancer and its clinical significance. Clin. Transl. Oncol. 2015, 17, 640-646. [CrossRef] [PubMed]

150. Nie, W.; Ge, H.J.; Yang, X.Q.; Sun, X.; Huang, H.; Tao, X.; Chen, W.S.; Li, B. IncRNA-UCA1 exerts oncogenic functions in non-small cell lung cancer by targeting miR-193a-3p. Cancer Lett. 2016, 371, 99-106. [CrossRef] [PubMed]

151. Katayama, S.; Tomaru, Y.; Kasukawa, T.; Waki, K.; Nakanishi, M.; Nakamura, M.; Nishida, H.; Yap, C.C.; Suzuki, M.; Kawai, J.; et al. Antisense transcription in the mammalian transcriptome. Science 2005, 309, 1564-1566. [PubMed]

152. Pichler, M.; Winter, E.; Stotz, M.; Eberhard, K.; Samonigg, H.; Lax, S.; Hoefler, G. Down-regulation of KRAS-interacting miRNA-143 predicts poor prognosis but not response to EGFR-targeted agents in colorectal cancer. Br. J. Cancer 2012, 106, 1826-1832. [CrossRef] [PubMed]

153. Huang, J.; Zhou, N.; Watabe, K.; Lu, Z.; Wu, F.; Xu, M.; Mo, Y.Y. Long non-coding RNA UCA1 promotes breast tumor growth by suppression of p27 (Kip1). Cell Death Dis. 2014, 5. [CrossRef] [PubMed]

154. Xu, S.; Wang, P.; You, Z.; Meng, H.; Mu, G.; Bai, X.; Zhang, G.; Zhang, J.; Pang, D. The long non-coding RNA EPB41L4A-AS2 inhibits tumor proliferation and is associated with favorable prognoses in breast cancer and other solid tumors. Oncotarget 2016, 7, 20704-20717. [CrossRef] [PubMed]

155. Chi, Y.; Huang, S.; Yuan, L.; Liu, M.; Huang, N.; Zhou, S.; Zhou, B.; Wu, J. Role of BC040587 as a predictor of poor outcome in breast cancer. Cancer Cell Int. 2014, 14. [CrossRef] [PubMed]

156. Shi, Y.; Li, J.; Liu, Y.; Ding, J.; Fan, Y.; Tian, Y.; Wang, L.; Lian, Y.; Wang, K.; Shu, Y. The long noncoding RNA SPRY4-IT1 increases the proliferation of human breast cancer cells by upregulating ZNF703 expression. Mol. Cancer 2015, 14. [CrossRef] [PubMed]

157. Cui, F.; Wu, D.; He, X.; Wang, W.; Xi, J.; Wang, M. Long noncoding RNA SPRY4-IT1 promotes esophageal squamous cell carcinoma cell proliferation, invasion, and epithelial-mesenchymal transition. Tumour Biol. 2016, 37, 10871-10876. [CrossRef] [PubMed] 
158. Liu, H.; Lv, Z.; Guo, E. Knockdown of long noncoding RNA SPRY4-IT1 suppresses glioma cell proliferation, metastasis and epithelial-mesenchymal transition. Int. J. Clin. Exp. Pathol. 2015, 8, 9140-9146. [PubMed]

159. Peng, W.; Wu, G.; Fan, H.; Wu, J.; Feng, J. Long noncoding RNA SPRY4-IT1 predicts poor patient prognosis and promotes tumorigenesis in gastric cancer. Tumour Biol. 2015, 36, 6751-6758. [CrossRef] [PubMed]

160. Ru, N.; Liang, J.; Zhang, F.; Wu, W.; Wang, F.; Liu, X.; Du, Y. SPRY4 Intronic Transcript 1 Promotes Epithelial-Mesenchymal Transition through Association with Snail1 in Osteosarcoma. DNA Cell Biol. 2016, 35, 290-295. [CrossRef] [PubMed]

161. Brzozowa, M.; Michalski, M.; Wyrobiec, G.; Piecuch, A.; Dittfeld, A.; Harabin-Slowinska, M.; Boron, D.; Wojnicz, R. The role of Snail1 transcription factor in colorectal cancer progression and metastasis. Contemp. Oncol. 2015, 19, 265-270. [CrossRef] [PubMed]

162. Hu, P.; Chu, J.; Wu, Y.; Sun, L.; Lv, X.; Zhu, Y.; Li, J.; Guo, Q.; Gong, C.; Liu, B.; et al. NBAT1 suppresses breast cancer metastasis by regulating DKK1 via PRC2. Oncotarget 2015, 6, 32410-32425. [PubMed]

163. Pandey, G.K.; Mitra, S.; Subhash, S.; Hertwig, F.; Kanduri, M.; Mishra, K.; Fransson, S.; Ganeshram, A.; Mondal, T.; Bandaru, S.; et al. The risk-associated long noncoding RNA NBAT-1 controls neuroblastoma progression by regulating cell proliferation and neuronal differentiation. Cancer Cell 2014, 26, 722-737. [CrossRef] [PubMed]

164. Collett, K.; Eide, G.E.; Arnes, J.; Stefansson, I.M.; Eide, J.; Braaten, A.; Aas, T.; Otte, A.P.; Akslen, L.A. Expression of enhancer of zeste homologue 2 is significantly associated with increased tumor cell proliferation and is a marker of aggressive breast cancer. Clin. Cancer Res. 2006, 12, 1168-1174. [CrossRef] [PubMed]

165. Kleer, C.G.; Cao, Q.; Varambally, S.; Shen, R.; Ota, I.; Tomlins, S.A.; Ghosh, D.; Sewalt, R.G.; Otte, A.P.; Hayes, D.F.; et al. EZH2 is a marker of aggressive breast cancer and promotes neoplastic transformation of breast epithelial cells. Proc. Natl. Acad. Sci. USA 2003, 100, 11606-11611. [CrossRef] [PubMed]

166. Bachmann, I.M.; Halvorsen, O.J.; Collett, K.; Stefansson, I.M.; Straume, O.; Haukaas, S.A.; Salvesen, H.B.; Otte, A.P.; Akslen, L.A. EZH2 expression is associated with high proliferation rate and aggressive tumor subgroups in cutaneous melanoma and cancers of the endometrium, prostate, and breast. J. Clin. Oncol. 2006, 24, 268-273. [CrossRef] [PubMed]

167. Wang, Y.; Liu, X.; Zhang, H.; Sun, L.; Zhou, Y.; Jin, H.; Zhang, H.; Zhang, H.; Liu, J.; Guo, H.; et al. Hypoxia-inducible lncRNA-AK058003 promotes gastric cancer metastasis by targeting gamma-synuclein. Neoplasia 2014, 16, 1094-1106. [CrossRef] [PubMed]

168. He, K.; Wang, P. Unregulated long non-coding RNA-AK058003 promotes the proliferation, invasion and metastasis of breast cancer by regulating the expression levels of the gamma-synuclein gene. Exp. Ther. Med. 2015, 9, 1727-1732. [PubMed]

169. Singh, V.K.; Jia, Z. Targeting synuclein-gamma to counteract drug resistance in cancer. Expert Opin. Ther. Targets 2008, 12, 59-68. [CrossRef] [PubMed]

170. Yang, F.; Liu, Y.H.; Dong, S.Y.; Ma, R.M.; Bhandari, A.; Zhang, X.H.; Wang, O.C. A novel long non-coding RNA FGF14-AS2 is correlated with progression and prognosis in breast cancer. Biochem. Biophys. Res. Commun. 2016, 470, 479-483. [CrossRef] [PubMed]

171. Yuan, S.X.; Yang, F.; Yang, Y.; Tao, Q.F.; Zhang, J.; Huang, G.; Yang, Y.; Wang, R.Y.; Yang, S.; Huo, X.S.; et al. Long noncoding RNA associated with microvascular invasion in hepatocellular carcinoma promotes angiogenesis and serves as a predictor for hepatocellular carcinoma patients' poor recurrence-free survival after hepatectomy. Hepatology 2012, 56, 2231-2241. [CrossRef] [PubMed]

172. Nie, F.Q.; Zhu, Q.; Xu, T.P.; Zou, Y.F.; Xie, M.; Sun, M.; Xia, R.; Lu, K.H. Long non-coding RNA MVIH indicates a poor prognosis for non-small cell lung cancer and promotes cell proliferation and invasion. Tumour Biol. 2014, 35, 7587-7594. [CrossRef] [PubMed]

173. Lei, B.; Xu, S.P.; Liang, X.S.; Li, Y.W.; Zhang, J.F.; Zhang, G.Q.; Pang, D. Long non-coding RNA MVIH is associated with poor prognosis and malignant biological behavior in breast cancer. Tumour Biol. 2016, 37, 5257-5264. [CrossRef] [PubMed]

174. Lin, A.; Li, C.; Xing, Z.; Hu, Q.; Liang, K.; Han, L.; Wang, C.; Hawke, D.H.; Wang, S.; Zhang, Y.; et al. The LINK-A lncRNA activates normoxic HIFlalpha signalling in triple-negative breast cancer. Nat. Cell Biol. 2016, 18, 213-224. [CrossRef] [PubMed]

(C) 2016 by the authors; licensee MDPI, Basel, Switzerland. This article is an open access article distributed under the terms and conditions of the Creative Commons Attribution (CC-BY) license (http://creativecommons.org/licenses/by/4.0/). 